\title{
EXHAUST EMISSION CHARACTERISTICS OF A GARDENER COMPRESSION IGNITION ENGINE FUELLED WITH RAPESEED METHYL ESTER AND FOSSIL DIESEL
}

\author{
H. A. Dandajeh ${ }^{1, *}$, Y. S. Sanusi ${ }^{2}$ and T. O. Ahmadu ${ }^{3}$ \\ 1, 2, 3, Department of MeChanical Engineering, Ahmadu Bello UniVersity, Zaria, KadunA State, NiGERIA \\ Email addresses: ${ }^{1}$ hadandajeh@yahoo.com, ${ }^{2}$ yinkasan@yahoo.com, ${ }^{3}$ talibahmadu@gmail.com
}

\begin{abstract}
This paper presents an experimental investigation into the exhaust emissions characteristics of a gardener Compression Ignition (CI) Engine fuelled with rapeseed methyl Esther (RME) and fossil diesel under lean equivalence ratios $(0.2 \leq \varphi \leq 0.8)$. The experiments were carried out at engine speeds of 750 and $1250 \mathrm{rpm}$ under five different loads. The experimental results showed that $\mathrm{NO}_{x}$ and $\mathrm{CO}_{2}$ emissions increased while emissions of $\mathrm{HC}, \mathrm{O}_{2}$ and $\mathrm{CO}$ decreased with increasing equivalence ratio, exhaust temperature, brake mean effective pressure and specific fuel consumption. All exhaust emissions were found to decrease with increasing engine speed from 750 to $1250 \mathrm{rpm}$. There was reduction in exhaust emissions of $\mathrm{RME}$ over fossil diesel by $0.06 \%$ for $\mathrm{O}_{2}$, $84 \%$ for $\mathrm{CO}$ and $4.7 \%$ for $\mathrm{CO}_{2}$ at $750 \mathrm{rpm}$. At higher speed of $1250 \mathrm{rpm}$ however, $\mathrm{RME}$ was observed having higher $\mathrm{NO}$ and $\mathrm{CO}_{2}$ but relatively lower $\mathrm{O}_{2}$ and $\mathrm{CO}$ than the fossil diesel.
\end{abstract}

Keywords-Exhaust Emission, Compression ignition engine, rapeseed methyl Esther, engine speed, fossil diesel

\section{INTRODUCTION}

For centuries, internal combustion engines either fuelled with gasoline or diesel fuels have immensely been supporting human endeavours. Latest statistics of the world oil proved reserve, production and consumption data as revealed by the British Petroleum [1] is shown in Table 1. Consumption of fossil fuels as shown on the Table is still on the rise despite various advances in producing much cleaner alternative fuels. For example, the world oil consumption has increased by $12.5 \%$ over the last decade (2008 to 2018) primarily due to growth in population and intensification of economic activities. Although the current proved reserve of the world oil currently stands at 244.1 billion tonnes/annum, two challenges are imminent. First, Organisation of Petroleum Exporting Countries (OPEC) could decide skyrocketing the global oil prices due to huge pressure (demand) on the reserve. Second, this demand action could also deplete the reserve and global environmental pollution is likely to increase. Fuels emanating from renewable sources have been found by several researchers to be much cleaner and most sustainable alternatives. Production of these alternative fuels from biological sources (biofuels) is usually carried out to augment such high fuel demand. Several feedstocks have been used by many researchers to produce biofuels. For example, Deka and Basumatary [2] produced sulphur free biodiesel from yellow oleander with the biodiesel having cetane number of 61.5. Others include Jathropa curcas [3], Neem Seed [4], Coconut Ethyl Ester [5] etc.

Performances of the biofuels in an engine are documented and exhaust emissions generated by burning biofuels mostly in compression ignition engines have also been analysed extensively. For example, Senatore et al. [6] carried out comparative analysis of combustion processes in direct injection diesel engine fuelled with diesel and rapeseed methyl ester (RME) under fuel rich regime (equivalence ratio $(\varphi)$ of $1.0-4.0$ ). Senatore et al. found that Diesel fuel had higher $\mathrm{CO}$ and emissions than RME with RME having higher NOx emissions in the fuel rich regime. Papakianakis et al. [7] studied the effect of dual

\footnotetext{
* Corresponding author, tel: +234-805-483- 4074
} 
fuelling (natural gas + diesel) and diesel fuels on the exhaust emissions. They found that exhaust emissions were reduced by about $50 \%$ especially at low and intermediate loads depending on engine operating conditions. With this emission reduction in mind, Zhang et al. [8] recently investigated the effect of low-level water addition on the combustion and emission characteristics. They found that adding lowlevel water up to $4 w t \%$ to diesel and RME significantly reduced exhaust emissions especially for $\mathrm{NOx}, \mathrm{CO}$ and $\mathrm{CO}_{2}$. Despite these contributions by researchers on biofuels, especially RME, there is hitherto little studies concerning the emission characteristics of RME in comparison with fossil diesel under lean conditions. The influence of combustion parameters on the exhaust emissions under low and high engine speeds are also rarely studied.

This paper therefore reports an experimental investigation into the exhaust emissions of Gardener Compression Engine fuelled with diesel and Rapeseed Methyl Ester under various loads and low and high operating speeds. Comparative analysis of the exhaust emissions of $\mathrm{CO}_{2}, \mathrm{CO}, \mathrm{HC}, \mathrm{O}_{2}, \mathrm{NOx}$ for both diesel and RME was carried out. Influence of engine parameters such as brake mean effective pressure (Bmep), equivalence ratio $(\varphi)$, specific fuel consumption (SFC) on the exhaust emissions was also reported.

\section{EXPERIMENTAL SYSTEMS AND METHODOLOGY}

The Gardener engine with model no $1 \mathrm{~L} 2$, is a fourstroke, single cylinder, direct injection compression ignition engine which is used to determine the influence of various fuel types at different experimental conditions. The engine has swept volume (Vs) which is 12 times the clearance volume (Vc). The Gardener engine used has four injector nozzles each with diameter of $220 \mu \mathrm{m}$ and injector opening pressure of $16.2 \mathrm{MPa}$. Table 2 shows the full specifications of the Gardener $1 \mathrm{~L} 2$ engine used for the experiment.

Table 1: World Oil Statistics 2019

\begin{tabular}{lllll}
\hline Region & $\begin{array}{l}\text { Proved Reserve } \\
10^{9} \mathrm{t} / \mathrm{yr}(2018)\end{array}$ & $\begin{array}{l}\text { Production } 10^{6} \mathrm{t} / \mathrm{yr} \\
(2018)\end{array}$ & $\begin{array}{l}\text { Consumption } 10^{6} \\
\text { toe/yr (2018) }\end{array}$ & $\begin{array}{l}\text { Consumption } 10^{6} \\
\text { toe/yr (2008) }\end{array}$ \\
\hline $\begin{array}{l}\text { North America } \\
\text { South and Central }\end{array}$ & 35.4 & 1027.1 & 1112.5 & 1105.3 \\
America & 51.1 & 335.1 & 315.3 & 287.9 \\
Europe & 1.9 & 162.9 & 742.0 & 817.1 \\
CIS & 19.6 & 709.1 & 193.5 & 174.7 \\
Middle East & 113.2 & 1489.7 & 412.1 & 351.1 \\
Africa & 16.6 & 388.7 & 191.3 & 156.5 \\
Asia Pacific & 6.3 & 361.6 & 1695.4 & 1250.2 \\
World & 244.1 & 4474.3 & 4662.1 & 4142.9 \\
\hline
\end{tabular}

Source: [1]. 1toe $=7.33$ barrels, toe $=$ tonnes of oil equivalent, $t=$ tonnes

Table 2: Gardner Engine Specifications

\begin{tabular}{lc}
\hline Parameters & Specifications \\
\hline Model & $1 \mathrm{~L} 2$ \\
No cylinders & $(\sigma) 1$ \\
Bore $(D)$ & $07.95 \mathrm{~mm}$ \\
Stroke $(S)$ & $152.4 \mathrm{~mm}$ \\
Swept volume & $1394.8 \times 10^{-6} \mathrm{~m}^{3}$ \\
(capacity) $\left(V_{s}\right)$ & $115.15 \times 10^{-6} \mathrm{~m}^{3}$ \\
Clearance volume $\left(V_{c}\right)$ & $14: 1$ \\
Compression ratio & $14.4 \mathrm{~kW} @ 1500$ \\
Max. power & $\mathrm{r} / \mathrm{min}$ \\
Inlet valve opening & $10^{\circ} \mathrm{btdc}$ \\
\hline
\end{tabular}

\begin{tabular}{lc}
\hline Parameters & Specifications \\
\hline Inlet valve closing & $40^{\circ}$ abdc \\
Exhaust valve opening & $50^{\circ} \mathrm{btdc}$ \\
Exhaust valve closing & $15^{\circ}$ atdc \\
Injection timing & $24.5^{\circ} \mathrm{btdc}$ \\
Injector nozzles & 4 \\
Nozzle throat dia & $220 \mu \mathrm{m}$ \\
Injector opening & $16.2 \mathrm{MPa}$ \\
pressure & \\
\hline $\begin{array}{l}\text { Where: atdc }=\text { after top dead centre, btdc = before } \\
\text { top dead centre, abdc= after bottom dead center, } \\
\text { bbdc = below bottom dead center }\end{array}$
\end{tabular}

Vol. 39, No. 3, July 2020 


\subsection{Experimental Procedure}

The experiment was carried out by taking readings at engine speeds of 750 and 1250rpm for a typical RME (rapeseed methyl ester) biodiesel and fossil diesel fuels. The engine was operated under five loads (4, $8,12,16$ and $18 \mathrm{~kg}$ ). Atmospheric pressure was initially measured at room temperature using a manometer mounted on the engine when a load of $4 \mathrm{~kg}$ was applied on the engine at a speed of 750rpm. The manometer measured the height of mercury in millimetre $(\mathrm{mm})$. The engine speed was set and measured using analogue tachometer. Fig. 1 shows a schematic of the experimental set up.

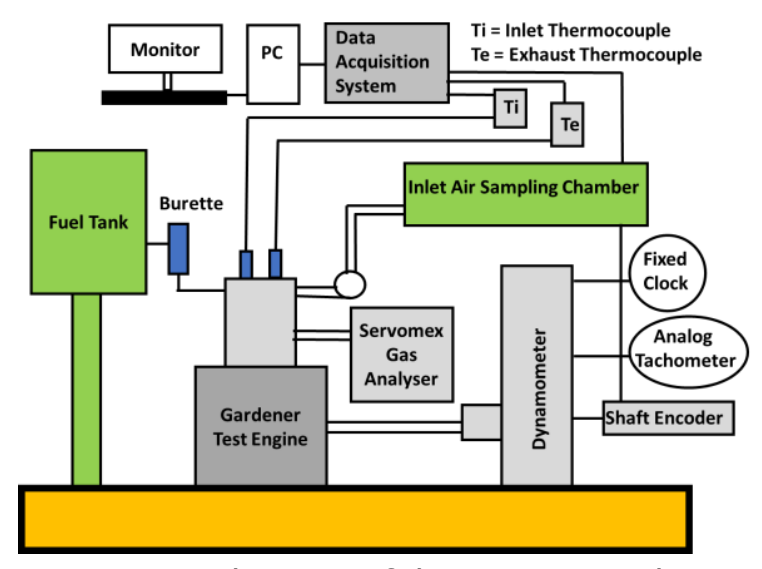

Fig. 1: Schematic of the Experimental Set-up

The inlet and exhaust temperatures were measured with a thermocouple while the time taken (in seconds) for the engine to consume $20 \mathrm{ml}$ of RME and diesel fuels was measured with a fixed clock mounted on the engine. The volume of the fuel was noted using a burette attached to the fuel tank. The Gardener engine was connected to a Desktop computer via a data acquisition system where the pressure readings (fuel line pressure, cylinder pressure and TDC positions) and exhaust temperature were measured. Emission readings of Carbon monoxide (CO), Carbon dioxide $\left(\mathrm{CO}_{2}\right)$ and excess oxygen $\left(\mathrm{O}_{2}\right)$ were measured and recorded from Servomex 4210C gas analyser. A Signal 4000VM chemiluminescence analyzer was used to measure NOx emission, while unburnt hydrocarbon $(\mathrm{HC})$ emissions were measured by a Rotork Analysis model 523 flame ionization detector (FID) analyser. Both analysers sampled exhaust gas via a heated line at $160^{\circ} \mathrm{C}$. The procedure was repeated for the remaining loads and for diesel fuel and all at a speed of $1250 \mathrm{rpm}$. All the afore-mentioned readings were also noted and recorded. Tables 3, 4, 5 and 6 show the inlet and exhaust readings recorded for RME and diesel fuels at engine speeds of 750 and 1250rpm.

\section{RESULTS AND DISCUSSION}

\subsection{Comparison of RME and Diesel Inlet and Exhaust Emissions Parameters}

Tables 3 and 4 show values for the inlet and exhaust parameters at a speed of 750rpm for RME and fossil diesel fuel respectively. Tables 5 and 6 show values for the inlet and exhaust parameters at a speed of 1250rpm for RME and fossil diesel fuel respectively. For the engine inlet parameters, it can be seen from the four tables that the manometer readings decreased with increasing engine load from $4-18 \mathrm{~kg}$ regardless of the fuel tested and for the speeds of both 750 and 1250rpm. For example, combustion of RME at a speed of 750rpm and inlet temperature of $13^{\circ} \mathrm{C}$ showed a reduction of manometer reading by $15 \%$ while combustion of diesel at the same speed and inlet temperature of $13^{\circ} \mathrm{C}$ showed reduction of manometer reading by only $10 \%$. At a relatively higher engine speed of $1250 \mathrm{rpm}$, the manometer readings were seen increasing for both fuels. On the other hand, variations of exhaust temperatures with increasing loads was observed to have an increasing trend and the exhaust temperatures were observed to be increasing with engine speed from 750 $1250 \mathrm{rpm}$. The time to consume $20 \mathrm{ml}$ of RME and diesel fuels for combustion was also found decreasing with engine loads.

Looking at Tables 3,4,5 and 6 for the raw exhaust emission data captured from the Sevomex $4210 \mathrm{C}$ gas analyser, it can be seen that emissions in excess oxygen, $\mathrm{O}_{2}(\%)$, carbon II oxide, $\mathrm{CO}(\%)$ and unburned hydrocarbon, $\mathrm{HC}(\mathrm{ppm})$ decreased with increasing loads for both RME and diesel fuels while emissions of Oxides of Nitrogen (NOx) increased with increasing load. These trends were also observed by Imran et al. [9]. In comparison with emissions from burning RME with combusting fossil diesel, RME was observed to have lower exhaust emissions than fossil diesel at the engine speed of 750rpm and at all the loads tested. At higher speed of 1250rpm however, RME was observed to be having higher $\mathrm{NOx}$ and $\mathrm{CO}_{2}$ but relatively lower $\mathrm{O}_{2}$ and $\mathrm{CO}$ than the fossil diesel. These results are consistent with those reported by Sentore et al. [6], but under rich equivalence ratios. Merkisz et al. [10] also reported RME having higher concentration of NOx emissions than fossil diesel fuel, and the emission quantity did not change even after using the exhaust gas after treatment system. For 
instance, at a load of $4 \mathrm{~kg}$ and engine speed of 750rpm, there was reduction in exhaust emissions of RME over fossil diesel by $0.06 \%$ for $\mathrm{O}_{2}, 84 \%$ for $\mathrm{CO}$ and $4.7 \%$ for $\mathrm{CO}_{2}$. Previous studies also reported reduction in $\mathrm{CO}, \mathrm{O}_{2}$ and $\mathrm{CO}_{2}$ but some under rich equivalence ratios [11- 13]. The implication of these observations is that RME can be a better substitute for a fossil diesel in a CI engine especially at low speed.

Table 3: RME parameters at speed of $750 \mathrm{rpm}$ at inlet temperature of $13^{\circ} \mathrm{C}$

\begin{tabular}{llllll}
\hline \multicolumn{7}{c}{ Inlet Parameters } & & \\
\hline Mass (kg) & 4 & 8 & 12 & 16 & 18 \\
Exhaust Temp (Tex), ${ }^{\circ} \mathrm{C}$ & 140.7 & 190.2 & 236.3 & 303.4 & 329.9 \\
Manometer height (mm) & 19.5 & 18.5 & 18 & 17.5 & 16.5 \\
Fuel time - t (s) & 122 & 86.67 & 64.86 & 50.56 & 45.23 \\
\hline \multicolumn{7}{l}{ Exhaust Emissions } & & & \\
\hline $\mathrm{O}_{2}(\%)$ & 16.67 & 14.4 & 12.12 & 9.73 & 8.03 \\
$\mathrm{CO}(\%)$ & 0.14 & 0.11 & 0.07 & 0.06 & 0.05 \\
$\mathrm{CO}_{2}(\%)$ & 2.81 & 4.4 & 6.07 & 7.75 & 8.86 \\
$\mathrm{NO}_{x}(\mathrm{ppm})$ & 297 & 580 & 823 & 995 & 920 \\
$\mathrm{HC}(\mathrm{ppm})$ & 390 & 400 & 290 & 240 & 280 \\
\hline
\end{tabular}

Table 4: Diesel parameters at speed of $750 \mathrm{rpm}$ at inlet temperature of $11^{\circ} \mathrm{C}$

\begin{tabular}{llllll}
\hline \multicolumn{7}{c}{ Inlet Parameters } \\
\hline Mass (kg) & 4 & 8 & 12 & 16 & 18 \\
Exhaust Temp (Tex), ${ }^{\circ} \mathrm{C}$ & 139 & 184.0 & 226.9 & 292.8 & 331.56 \\
Manometer height (mm) & 19.5 & 19.0 & 18.5 & 18.0 & 17.5 \\
Fuel time - t (s) & 128 & 88.62 & 66.97 & 50.28 & 43.56 \\
\hline \multicolumn{7}{c}{ Exhaust Emissions } \\
\hline $\mathrm{O}_{2}(\%)$ & 16.84 & 14.84 & 12.57 & 9.74 & 8.74 \\
$\mathrm{CO}(\%)$ & 0.89 & 0.504 & 0.372 & 0.257 & 0.280 \\
$\mathrm{CO}_{2}(\%)$ & 2.95 & 4.44 & 6.07 & 8.01 & 9.33 \\
$\mathrm{NO}_{\times}(\mathrm{ppm})$ & 279 & 609 & 955 & 1210 & 1270 \\
$\mathrm{HC}(\mathrm{ppm})$ & 133.2 & 130.7 & 121.9 & 72.8 & 60.2 \\
\hline
\end{tabular}

Table 5: RME fuel results at speed of $1250 \mathrm{rpm}$ at inlet temperature of $14^{\circ} \mathrm{C}$

\begin{tabular}{llllll}
\hline \multicolumn{5}{c}{ Inlet Parameters } \\
\hline Mass (kg) & 4 & 8 & 12 & 16 & 18 \\
Exhaust Temp (Tex), ${ }^{\circ} \mathrm{C}$ & 183.18 & 232.81 & 293.01 & 371.37 & 383.43 \\
Manometer height (mm) & 46 & 45 & 43.5 & 41.5 & 37.5 \\
Fuel time - t (s) & 67.61 & 47.92 & 37.13 & 28.98 & 26.1 \\
\hline \multicolumn{5}{c}{ Exhaust Emissions } \\
\hline $\mathrm{O}_{2}(\%)$ & 15.89 & 13.71 & 11.21 & 8.05 & 7.47 \\
$\mathrm{CO}(\%)$ & 0.12 & 0.1 & 0.008 & 0.08 & 0.09 \\
$\mathrm{CO}_{2}(\%)$ & 3.58 & 5.23 & 7.12 & 9.46 & 10.27 \\
$\mathrm{NO}_{x}(\mathrm{ppm})$ & 373 & 271 & 936 & 980 & 1045 \\
$\mathrm{HC}(\mathrm{ppm})$ & 323.3 & 277.7 & 254.1 & 239.5 & 264.4 \\
\hline
\end{tabular}


Table 6: Diesel parameters at speed of $1250 \mathrm{rpm}$ at inlet temperature of $17^{\circ} \mathrm{C}$

\begin{tabular}{llllll}
\hline \multicolumn{5}{c}{ Inlet Parameters } \\
\hline Mass (Kg) & 4 & 8 & 12 & 16 & 18 \\
Exhaust Temp (Tex), ${ }^{\circ} \mathrm{C}$ & 164.16 & 209.36 & 263.14 & 338.4 & 364.5 \\
Manometer height (mm) & 49 & 45.5 & 45.5 & 44 & 43.5 \\
Fuel time - t (s) & 73.79 & 51.64 & 39.01 & 30.26 & 29.17 \\
\hline \multicolumn{5}{c}{ Exhaust Emissions } \\
\hline $\mathrm{O}_{2}(\%)$ & 16.65 & 14.47 & 12.12 & 9.0 & 8.11 \\
$\mathrm{CO}(\%)$ & 0.888 & 0.6 & 0.008 & 0.08 & 0.09 \\
$\mathrm{CO}_{2}(\%)$ & 3.15 & 4.72 & 6.39 & 8.47 & 8.8 \\
$\mathrm{NO}_{\mathbf{x}}(\mathrm{ppm})$ & 196 & 585 & 970 & 1268 & 1308 \\
$\mathrm{HC}(\mathrm{ppm})$ & 108.5 & 127.1 & 96 & 50.1 & 49 \\
\hline
\end{tabular}

\section{1 Variations of Exhaust emissions with equivalence ratio}

This section reports variations of exhaust emissions with equivalence ratio $(\varphi)$ normalised with values computed from the specific fuel consumptions (SFC). Variations of equivalence ratio with carbon (iv) oxide emission is presented in Fig.2a. It can be observed from Fig.2a that $\mathrm{CO}_{2}$ emission increased with an increase in equivalence ratio $(\varphi=0.2-0.8)$. With increasing operating speed from $750-1250 \mathrm{rpm}$, the $\mathrm{CO}_{2}$ emission was found to decrease. This behaviour of increased $\mathrm{CO}_{2}$ emission is not surprising since increasing the equivalence ratio means introducing more carbon-based fuel into the engine and therefore $\mathrm{CO}_{2}$ emission as one of the principal combustion products is also expected to increase. However, Fig. $2 b$ represents a graph for the emissions of carbon monoxide (CO) with equivalence ratio. It can be seen from the graph that increasing equivalence ratio $(\varphi)$ from 0.2 to 0.8 limits the production of $\mathrm{CO}$ drastically, especially at a speed of 750 rpm. CO emission was also reduced at higher speed of $1250 \mathrm{rpm}$ at equivalence ratios ranging from $0.2-0.48$. The result for the decreased $\mathrm{CO}$ emission signifies near complete combustion for RME.

Fig.2c shows the variations of oxygen emissions with equivalence ratio. Like the trend of $\mathrm{CO}$ emissions, oxygen $\left(\mathrm{O}_{2}\right)$ emission was also observed decreasing with increasing equivalence ratio regardless of the engine operating speed. This is expected since increased equivalence ratio signifies increased fuel consumption. This consequently leads to the use of most air $\left(\mathrm{O}_{2}\right)$ in the combustion chamber leaving only small amount of excess $\mathrm{O}_{2}$ to be emitted. Taking closer look at Fig.2c, the difference on the influence of the two engine speeds on the $\mathrm{O}_{2}$ emission at $\varphi=$ 0.3 remains insignificant. Equivalence ratio of 0.3 shows that the $\mathrm{O}_{2}$ emission of $2200 \mathrm{~g} / \mathrm{MJ}$ is the same at both speeds of 750 and 1250rpm. This Margin of $\mathrm{O}_{2}$ emission slightly increased to $250 \mathrm{~g} / \mathrm{MJ}$, with the 750rpm at slightly higher speed. Fig.2d shows variation of unburned hydrocarbon $(\mathrm{HC})$ emissions with equivalence ratio. It can be seen from the graph that increase in equivalence ratio results in corresponding decrease in $\mathrm{HC}$ emissions. This trend continues until at $\varphi=0.5$ in which the trend reverses. Production of $\mathrm{HC}$ is also triggered by incomplete combustion as results of uncontrolled vaporization of fuels. Imran et al. [9] also reported variations of $\mathrm{HC}$ emissions similar to those in this work.

Nitrous oxide emissions (NOx) has been shown to vary with equivalence ratio in Fig.2e. It is apparent from Fig.2e that NOx production is triggered at lower speed with increased equivalence ratio. This also buttress that the higher the engine speed, the lower the tendency of NOx emissions. For example, at ultralean equivalence ratio of 0.3 , the NOx emission is $9.0 \mathrm{~g} / \mathrm{MJ}$ and it reduced to $8.0 \mathrm{~g} / \mathrm{MJ}$ when the speed was increased to $1250 \mathrm{rpm}$. At higher equivalence ratio approaching stoichiometric, say $\varphi=0.6$, the NOx emission was seen increasing significantly to $11.4 \mathrm{~g} / \mathrm{MJ}$ at 750rpm and reduced remarkably to $8.7 \mathrm{~g} / \mathrm{MJ}$ when the speed was increased to $1250 \mathrm{rpm}$. 

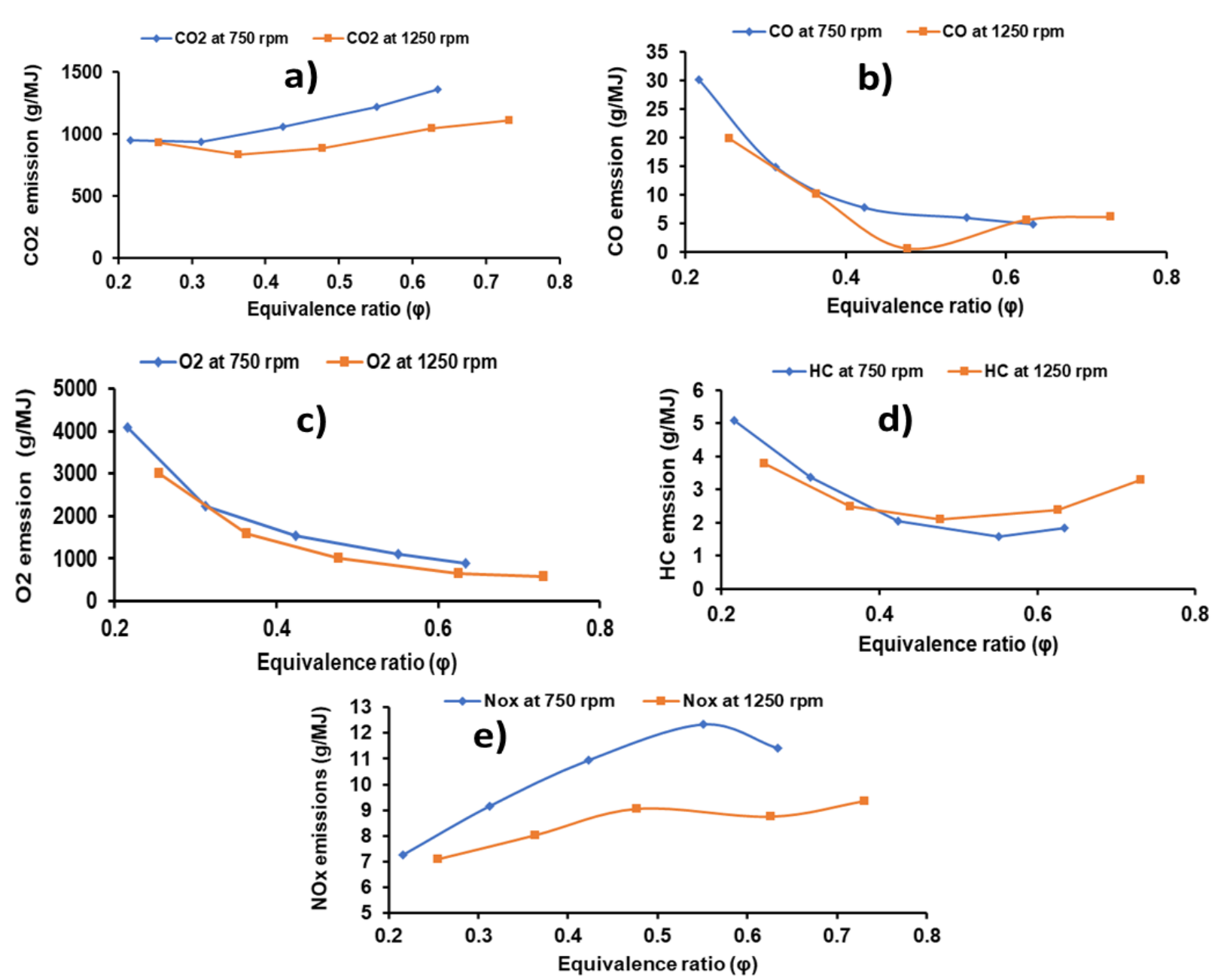

Fig.2: Variations of exhaust emissions with equiablence ratio ( $\varphi$ ) a) $\mathrm{CO}_{2}$ b) $\mathrm{CO}$ c) $\mathrm{O}_{2}$ d) $\mathrm{HCe}$ ) $\mathrm{NOx}$

\subsection{Variations of Exhaust emissions with Bmep}

Fig.3a shows a graph for the variations of $\mathrm{CO}$ emissions with brake mean efffective pressure (bmep). It can be seen from Fig.3a that, at a speed of 750rpm, $\mathrm{CO}_{2}$ emissions increased from $931-1359$ $\mathrm{g} / \mathrm{MJ}$ when bmep increased from 0.13 to $0.57 \mathrm{MPa}$. Similar trend for $\mathrm{CO}_{2}$ emissions can be seen at a speed of 1250rpm although at lower concentrations. Fig. $3 \mathrm{~b}$ shows the graph of the variations of $\mathrm{CO}$ emissions with bmep. The figure rather shows decreasing trend of $\mathrm{CO}$ emissions with increasing bmep especially for loads of $4-12 \mathrm{~kg}$ with the speed of 750rpm having higher $\mathrm{CO}$ emissions. This behaviour is in line with previous studies [14], A turning point can be seen from Fig.3b at a load of $12 \mathrm{~kg}$ where $\mathrm{CO}$ emissions started increasing for both speeds. Fig. $3 \mathrm{c}$ and $3 \mathrm{~d}$ demonstrate variations of bmep with $\mathrm{O}_{2}$ and $\mathrm{HC}$ emissions respectively. It can be seen from both graphs that increasing Bmep within the range of $0.13-0.57 \mathrm{MPa}$ resulted in increase in $\mathrm{O}_{2}$ and $\mathrm{HC}$ emissions, with the emission values at engine speed at 750rpm higher than those at $1250 \mathrm{rpm}$. This variation of Bmep with $\mathrm{O}_{2}$ and $\mathrm{HC}$ emissions is also similar with those of $\mathrm{CO}$ emission.

Fig.3e shows the variations of NOx emissions with bmep. It can be observed from the figure that the NOx emissions increased with increasing bmep especially for the three loads $(4-12 \mathrm{~kg}$ ) and for all the engine speed tested. For loads ranging from $16-$ $18 \mathrm{~kg}$, there seemed to be slight decrease and increase in NOx emissions for speeds of 750 and 1250rpm respectively. Taking closer inspection of Fig.3e, NOx emissions were found to be higher with speed increase from $750-1250 \mathrm{rpm}$. Crookes and Bob-Manuel [14] also reported increased NOx emission with increasing Bmep from 0.2 to $0.5 \mathrm{MPa}$ for both RME and DME fuels. 

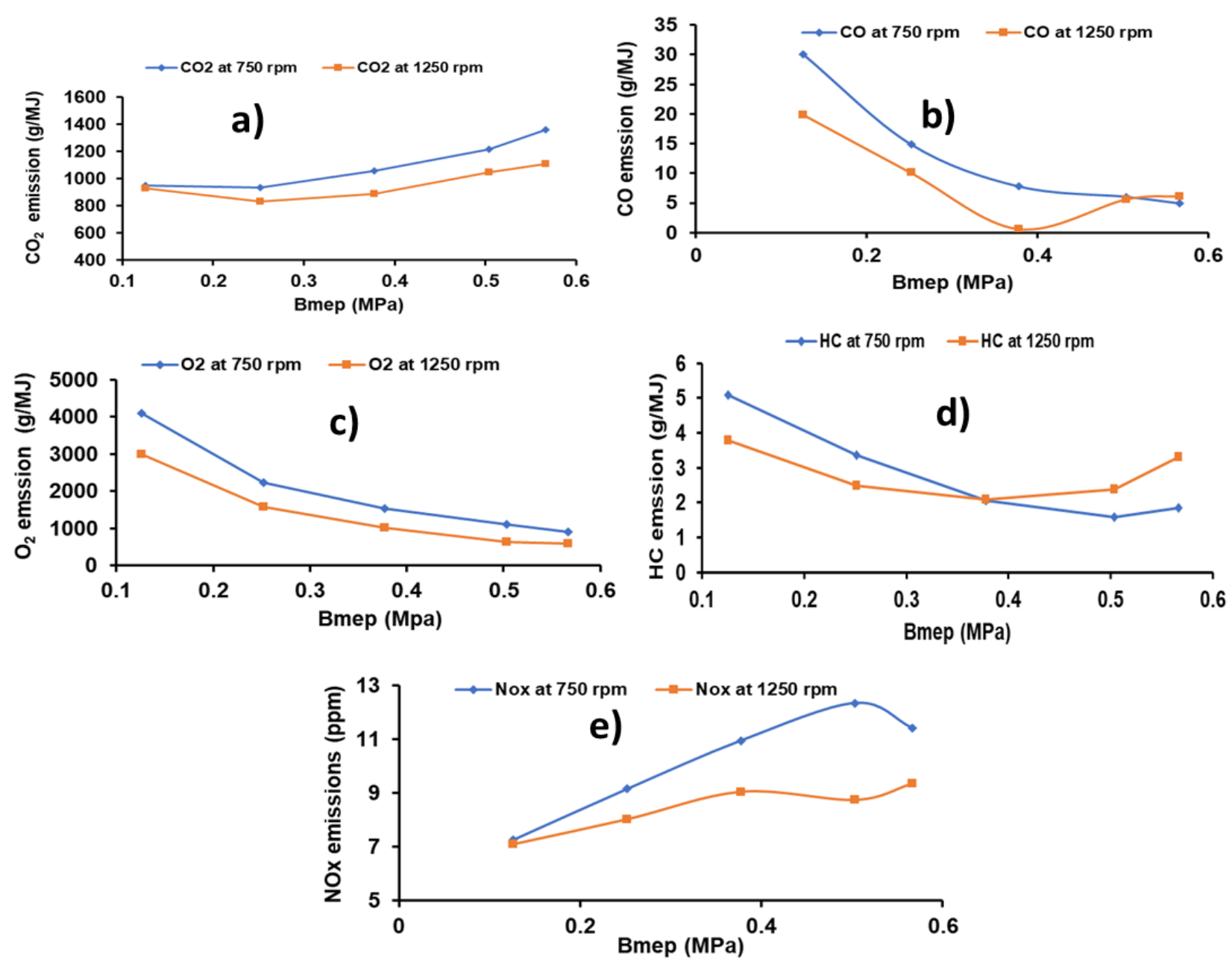

Fig.3: Variations of exhaust emissions with brake mean effective pressure (Bmep) ( $\varphi$ ) a) $\mathrm{CO}_{2}$ b) $\mathrm{CO}$ c) $\mathrm{O}_{2}$ d) $\mathrm{HC}$ e) NOx

\subsection{Variations of Exhaust emissions with Specific Fuel Consumption (SFC)}

Fig.4 shows variations of representative exhaust emissions with specific fuel consumption (SFC). Fig.4a shows the variations of carbon mono oxide (CO) emissions with SFC. It can be seen from Fig.4a that $\mathrm{CO}$ emissions decreased with increasing engine speed from 750 to $1250 \mathrm{rpm}$ irrespective of the engine load. Fig.4a also demonstrates that $\mathrm{CO}$ emissions becomes more pronounced at higher specicific fuel consumption and it drastically reduced with increasing engine load. At the speed of 750 rpm for instance, $\mathrm{CO}$ emissions was found to be $30 \mathrm{~g} / \mathrm{MJ}$ at a load $4 \mathrm{~kg}$ and it markedly decreased to $4.9 \mathrm{~g} / \mathrm{MJ}$ (84\% reduction) at the highest load of $18 \mathrm{~kg}$. Fig. $4 \mathrm{~b}$ shows the variations of emissions levels of $\mathrm{O}_{2}$ with the SFC at speeds of 750 and $1250 \mathrm{rpm}$ for the four different loads. It can be observed from Fig.2b that $\mathrm{O}_{2}$ emissions decreased with increased engine speed from 750 to $1250 \mathrm{rpm}$ regardless of the engine load. On the other hand, when more fuel was consumed (higher SFC), the emissions levels of $\mathrm{O}_{2}$ is seen to be the highest. The explanation to this phenomenon is basic. As more fuel is consumed, more oxygen is needed for complete combustion. When the exact quantity of oxygen is consumed and burnt, the excess oxygen is then emitted as shown in Fig.4b.

Fig.4c presents the emissions of oxides of Nitrogen (NOx) with SFC. It can be seen from Fig.4c that NOx emissions increased with decreasing SFC and increasing engine load at the two speeds tested. The figure also showed that NOx emission was slightly higher at 750rpm than at $1250 \mathrm{rpm}$ regardless of the engine load. This trend of increasing NOx for RME has also been seen already in Fig.2e (with equivalence ratio) and Fig.3e (with brake mean effective pressure). 

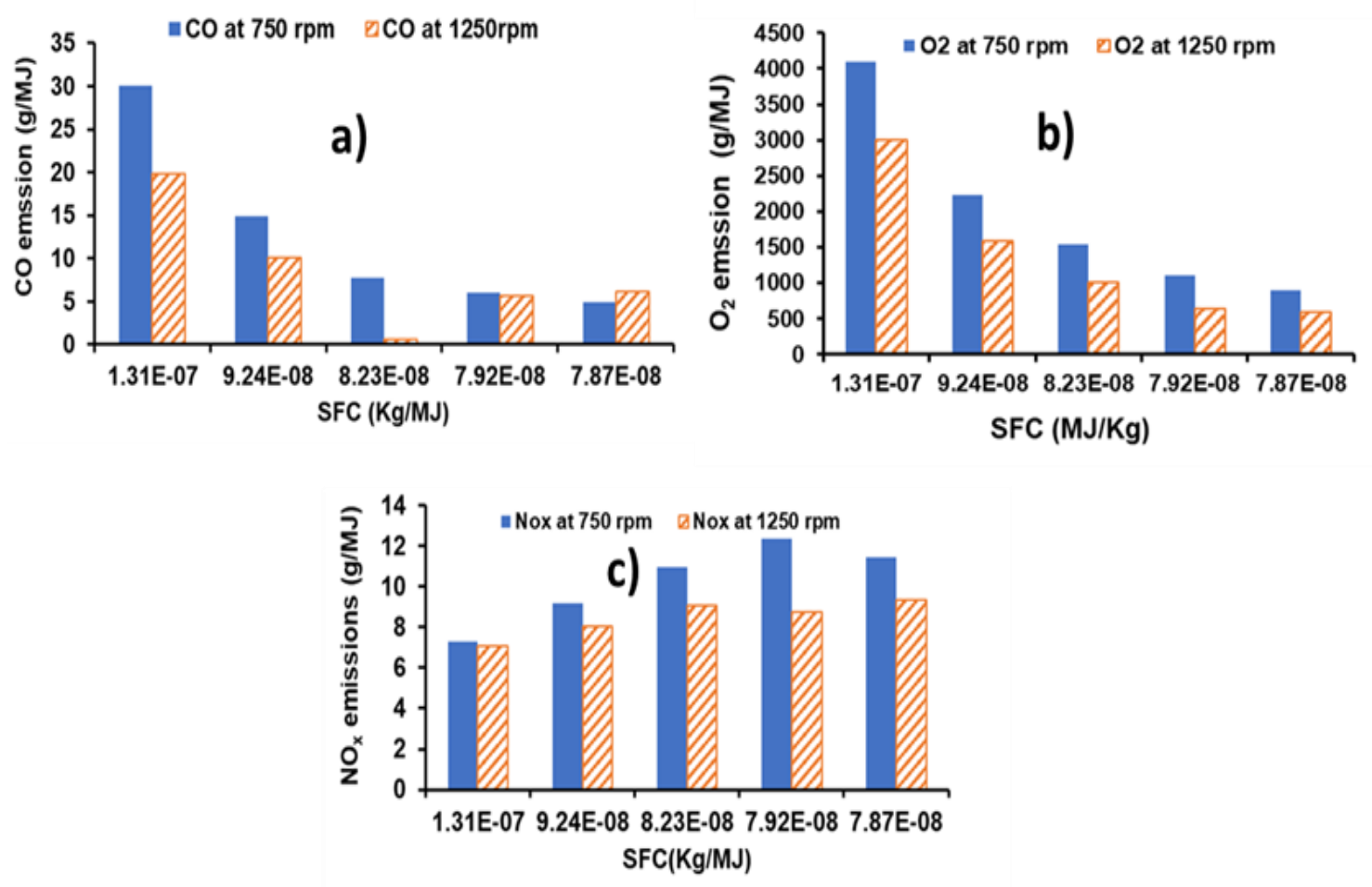

Fig.4: Variations of exhaust emissions with specific fuel consumptio ( $\varphi$ ) a) $\mathrm{CO}$ b) $\mathrm{O}_{2}$ c) $\mathrm{NOx}$

Lastly, as it is available from most literatures, an ideal combustion in a CI engine should yield high bmep, faster combustion process and higher efficiency with a clean exhaust emission and less noise [15]. However, these are entirely competing requirements for an RME fuel. For instance, Dandajeh and Ahmadu [16] found that the output of the engine (bmep) increased with air-fuel ratio, equivalence ratio and exhaust gas temperatures with decrease in volumetric efficiency. This decrease in bmep could lead to an increase in $\mathrm{CO}_{2}$ and $\mathrm{NO}_{x}$ (see Fig3a \& $3 \mathrm{e}$ ) emissions but decrease in $\mathrm{O}_{2}$, $\mathrm{CO}$ and $\mathrm{HC}$ emissions (see Figs.3b, 3c and 3d) at both $750 \mathrm{rpm}$ and $1250 \mathrm{rpm}$ operating speeds. To support this, Horn et al. [17] reported that high distillation curve gradient of RME is responsible for its $\mathrm{CO}$ and $\mathrm{HC}$ emissions. It is also worth noting that $\mathrm{HC}$ production is being triggered by incomplete combustion as a result of vaporization of RME and at lower distillation temperature. Moreover, $\mathrm{NO}_{x}$ emissions could be reduced by emulsifying the RME fuel due to dissociation and consequent evaporation of water which decreases the maximum temperature [18]. Therefore, it is quite imperative to increase the bmep of this engine by turbocharging [19]. As with the case of high exhaust temperatures, this practically means much work will be extracted by the turbines at the exhaust.

\section{CONCLUSION}

An experimental investigation on the exhaust emissions of rapeseed methyl Esther (RME) and fossil diesel in a gardener Compression Ignition Engine was presented. The Gardener engine has a compression ratio of $14: 1$ and a maximum speed of $1500 \mathrm{rpm}$. Experiments were carried out at two engine speeds, an intermediate low-speed of 750rpm and intermediate high-speed of $1250 \mathrm{rpm}$. The engine was operated under five loads $(4,8,12,16$ and $18 \mathrm{~kg})$ and under lean equivalence ratios $(0.2 \leq \varphi \leq 0.8)$. The following conclusions were drawn.

i) Emissions of $\mathrm{NO}_{x}$ and $\mathrm{CO}_{2}$ increased while those of $\mathrm{HC}, \mathrm{O}_{2}$ and $\mathrm{CO}$ decreased with increasing equivalence ratio, exhaust temperature (Tex), brake mean effective pressure (bmep) and specific fuel consumption (SFC).

ii) Values of all the exhaust emissions $\left(\mathrm{NO}_{x}, \mathrm{CO}_{2}\right.$, $\mathrm{HC}, \mathrm{O}_{2}$ and $\mathrm{CO}$ ) were found to decrease with increasing engine speed from 750 to $1250 \mathrm{rpm}$.

iii) RME was observed having lower exhaust emissions than fossil diesel at the engine speed of 750rpm and at all the loads tested.

iv) Emission reduction of RME over fossil diesel was achieved by $0.06 \%$ for $\mathrm{O}_{2}, 84 \%$ for $\mathrm{CO}$ and $4.7 \%$ for $\mathrm{CO}_{2}$ at $750 \mathrm{rpm}$. At higher speed of $1250 \mathrm{rpm}$ however, RME was observed having 
higher $\mathrm{NOx}$ and $\mathrm{CO}_{2}$ but relatively lower $\mathrm{O}_{2}$ and $\mathrm{CO}$ than the fossil diesel.

v) The implication of these observations is that RME can be a better substitute for a fossil diesel in a CI engine especially at low speed.

\section{ACKNOWLEDGEMENTS}

Hamisu Adamu Dandajeh wishes to gratefully acknowledge the Petroleum Technology Development Fund (PTDF) for sponsoring his Post Graduate Studies at the Queen Mary University of London, United Kingdom

\section{REFERENCES}

[1] British Petroleum (BP) statistical World Energy Review (2019).pdf.

[2] Deka, D.C and Basumatary, S. "High Quality biodiesel from yellow orleander (Thevetia peruviana) seed oil". Biomass and Bioenergy.Vol.3, 2011, pp. $1797-1803$.

[3] Bringi, N. V. Non- traditional oilseeds and oils of India. New Delhi: Oxford \& IBH Publishing Co. Pvt. Ltd. 1987.

[4] Azam M.M, Waris A, Nahar N. M. "Prospects and potential of fatty acid methyl esters of some nontraditional seed oils for use as biodiesel in India". Biomass. Bioenergy. Vol.29, 2005, pp 293-302.

[5] Samuel, O. D., F. I. Ashiedu 2 and B. U. Oreko. "Analysis of coconut ethyl ester (biodiesel) and fossil diesel Blending: properties and corrosion characteristics". Nigerian Journal of Technology (NIJOTECH) Vol. 35, Number 1, 2016, pp. 107 113.

[6] Senatore, A, Cardon M, Rocco V, and Prati M. V. A "Comparative Analysis of Combustion Process in D. I. Diesel Engine Fueled with Biodiesel and Diesel Fuel". SAE Technical Paper Series, 2000.

[7] Papagiannakis R. G, Hountalas D.T. "Combustion and exhaust emission characteristics of a dual fuel compression ignition engine operated with pilot diesel fuel and natural gas". Energy Conversion and Management. Vol.45, 2004, pp 77- 87.

[8] Zhang Z, Jiaqiang $E$, Jingwei $C$, Hao $Z$, Xiaohuan Z, Dandan H, Wei Z, Qingguo P, Jinke G, Zibin Y. "Effects of low-level water addition on spray, combustion and emission characteristics of a medium speed diesel engine fuelled with biodiesel fuel". Fuel. 2019, pp. 245-262.
[9] Imran, S., Emberson D.R., Wen, D.S., Diez, A, Crookes, R.J, Korakianitis T., "Performance and specific emissions contours of a diesel and RME fuelled compression ignition engine throughout its operating speed and power range" Applied Energy. Vol. 111, 2013, pp.771- 777.

[10] Merkisz, J., Fuć .P., Lijewski, P., and Kozak, M "Rapeseed Oil Methyl Esters (RME) as Fuel for Urban Transport". Chapter IntechOpen. (2016). Pp.24 -39.

[11] Namasivayam, A. M, R J Crookes, T Korakianitis, ] Olsen "Assessment of combustion in natural gas dual-fuelled compression ignition engines with dimethyl ether and rapeseed methyl ester pilot ignition". International Journal of Engine Research, Vol.10 Number 3, 2009, pp.165-174.

[12] Park, S.H. \& Lee, C.S. "Combustion performance and emission reduction characteristics of automotive DME engine system". Progress in Energy and Combustion Science, Vol. 39, Number 1, 2013, pp.147-168.

[13] Shoba, T.T. "Optical Characterisation of Diesel, RME and Kerosene Sprays by Microscopic Imaging 1" Centre for Automotive Engineering, University of Brighton, UK 2: BP Global Fuels Technology, Pangbourne, RG8 7QR, UK. , 2011, pp.1-9.

[14] Crookes, R.J. \& Bob-Manuel, K.D.H. "RME or DME: A preferred alternative fuel option for future diesel engine operation". Energy Conversion and Management, vol.48, Number 11, 2007, pp 2971-2977.

[15] Richard Stone, Introduction to Internal Combustion Engines. London: Macmillan Publishers Itd, 1985.

[16] Dandajeh, H.A and Ahmadu T.O "Engine Performance of a Gardener Compression Ignition Engine using Rapeseed Methyl Esther". FUOYE Journal of Engineering and Technology. 2019, 4(2), pp.126-130.

[17] Horn, U., Egnell, R. \& Andersson, Ö. "Fuel Dependent Heat Release Differences between Euro Diesel Fuel and RME in a HSDI Diesel Engine", Open Seminar on Alternative Fuels for Engines. 2006, pp.1 -6.

[18] Cisek, J. "Injection and Combustion of RME with Water Emulsions in a Diesel Engine". Acta polytechnica, vol.50, Number 2, 2010, pp 3745.

[19] Heyhood J.B. Internal Combustion Engines fundamentals. Singapore: McGrawHill, 1988. 